Central Ukrainian National Technical University, Kropivnitskiy, Ukraine

\title{
Investigation of the Effectiveness of Coatings on the Basis of Zinc and Aluminum in Chloride-sulfide Media
}

The aim of the study is to investigate the effectiveness of protective coatings: hot galvanizing, metallization aluminum and combined metal polymer: metallization aluminum with epoxy coating for possible protection against hydrogen sulfide corrosion.

To determine the possibility of protection steels from hydrogen sulfide corrosion and corrosion cracking, zinc coatings, applied with hot dip galvanizing, metallized aluminum coatings, applied by electro-arc spraying and combined metallization aluminum + epoxy in media of different aggressiveness were investigated. It is shown that the application of zinc coating on 20 steel increases the corrosion resistance on average in 1.5 times in model sea water (MSW) without hydrogen sulfide and almost in 2 times in the MSW saturated with hydrogen sulfide compared with that for non-coated 20 steel. In the NACE solution, the corrosion resistance of samples with zinc coating is sharply reduced, which indicates the inexpediency of the use of such coatings in acidic environments. Examples of aluminum coatings showed high corrosion resistance in MSW with different content of hydrogen sulfide and in NACE solution: the corrosion rate of steel with aluminum coating is reduced in 7.3 times in the MSW saturated with hydrogen sulfide and in 1.7 times in NACE solution compared to the corrosion rate of steel without coating.

Investigation of the susceptibility to stress corrosion cracking showed that samples with an aluminum coating showed higher resistance to hydrogen sulfide stress corrosion cracking than samples without coating. And samples with a combined coating (metallic aluminum + Jotamastic 87GF) showed better protective properties than samples with aluminum coating. Aluminum coatings applied by the method of electric arc spraying on 20 steel and combined coatings can be recommended for the protection of metal surfaces in hydrogen sulfide media of different aggressiveness.

coating, hot galvanizing, electric arc spraying, hydrogen sulfide, corrosion rate, corrosion cracking

Одержано (Received) 20.11.2018

Прорецензовано (Reviewed) 05.02.2019

Прийнято до друку (Approved) 04.06.2019

УДК 553.04

DOI: https://doi.org/10.32515/2664-262X.2019.1(32).93-102

В.М. Кропівний, проф., канд. техн. наук, Л.А. Молокост, викл., О.В. Кузик, доц., канд. техн. наук, А.В. Кропівна, доц., канд. техн. наук

Центральноукраӥнський наџіональний технічний університет, м. Кропивницький, Україна

e-mail: Lyudmila.Molokost1967@gmail.com

\section{Порівняльна промислова оцінка графітових родовищ та руд України, характеристика збагачення руд}

В статті розглянуто основні родовища графіту в Україні, методи збагачення графітових руд в залежності від ступеню їх фізико-хімічних змін, зроблено порівняльну промислову оцінку родовищ та визначені найбільш перспективні для освоєння об'єкти.

На прикладі трьох найбільших родовищ графіту Українського щита розглянута проблема збагачення графітових руд, а також принципи їх поділу на промислові типи, дана характеристика графітовим рудам і властивостям графіту, застосування графіту в промисловості. Властивості цього мінералу дозволяють використання його, як і вуглецю в цілому, у всіх галузях народного господарства, науки та техніки. Основні галузі застосування природного графіту: - металургія (виробництво тиглів, ливарних форм, вогнетривів, протипригарних фарб); - нафтогазова галузь; - електрохімія; машинобудування, авіаційна та космічна техніка(гальмівні колодки і накладки, самозмащувальні механічні частини - підшипники і вкладки).Визначені особливості кон'юнктури ринку графіту, що передбачає аналіз динаміки видобутку, виробництва, споживання мінеральної сировини в Україні та світі.

графіт, графітові родовища, якість, запаси, збагачення руд

() В.М. Кропівний, Л.А. Молокост, О.В. Кузик, А.В. Кропівна, 2019 
В.Н. Кропивный, проф., канд. техн. наук, Л.А.Молокост, викл., А.В. Кузык, доц., канд. техн. наук, А.В. Кропивна, доц., канд. техн. наук

Кировоградский наичиоальный технический университет г. Кропивницкий, Украина

Сравнительная промышленная оценка графитовых месторождений и руд

Украины, характеристика обогащения руд

В статье рассмотрены основные месторождения графита на Украине, методы обогащения графитовых руд в зависимости от степени их физико-химических изменений, сделана промышленная оценка, определены наиболее перспективные для освоения объекты.

На примере трех наибольших месторождений графита Украинского щита рассмотрена проблема обогащения графитовых руд, а также принципы их разделения на промышленные типы, дана характеристика графитовым рудам свойствам графита, применение графита в промышленности. Основные области применения природного графита: - металлургия (производство тиглей, литейных форм, огнеупоров, противопригарные красок) - нефтегазовая отрасль; - електрохимия; машиностроение, - авиационная и космическая техника (тормозные колодки и накладки, самосмазывающиеся механические части - подшипники и вкладки).Определены особенности коньюктуры рынка графита, что предусматривает анализ динамики добычи, производства, потребления минерального сырья в Украине та мире.

графит, графитовые месторождения, качество, запасы, обогащение руд

Постановка проблеми. Родовища та прояви графіту утворюють на території України чотири графітоносні райони і входять до єдиної Української графітоносної провінції. Всього на території України, окрім балансових родовищ налічується також близько 100 рудопроявів та 400 точок підвищеної графітової мінералізації. Більшість із цих об'єктів пройшли лише попередню оцінку або віднесені до прогнозних ресурсів і вивчені недостатньо. Тією чи іншою мірою розвідані лише деякі рудопрояви (їх запаси віднесені до категорій $\left.\mathrm{A}, \mathrm{B}, \mathrm{C}_{1}+\mathrm{C}_{2}\right)$, які раніше вважались родовищами, але, в результаті дорозвідки більш перспективних об'єктів, втратили першочергову промислову значимість (Водянське, Бабенківське, Старокримське).

На сьогоднішній день виробництво кристалічного графіту в Україні зменшується. Цей факт вимагає визначення нових перспективних об'єктів видобутку, причому з сировиною відповідної якості. Нові родовища графіту, розвідані за останні десятиліття, можуть скласти значну конкуренцію раніше розвіданим об'єктам і служити базою для створення нових промислових осередків графітовидобутку в Україні.

Аналіз останніх досліджень і публікацій. Україна $є$ однією з перших серед країн СНД за запасами, видобутком руди та виробництвом кристалічного графіту. Графітоносність Українського щита (УЩ) досліджували Є.П. Петровський та Н.І. Безбородько. Питання промислових типів руд графітових родовищ Українського щита в науковій літературі розглядались А. Д. Додатком та Н. Н. Янгічером, а основні дослідження в галузі збагачення руд були проведені В. Б. Чижевським, М. В Бондаренко, Н. С. Власовою та ін. Розробка схем та режимів збагачення графітових руд проводилась Інститутом мінеральних ресурсів (м.Сімферополь). Технологічні дослідження збагачуваності різних типів графітових руд були виконані Завалівським гірничозбагачувальним комбінатом (ГЗК).

Постановка завдання. Метою роботи є огляд основних родовищ графіту та характеристика промислових типів руд найбільших за запасами графіту родовищ Українського щита, порівняти області застосування продуктів збагачення за результатами лабораторних та напівпромислових досліджень, визначити основні проблеми, пов'язані з їх збагаченням та розглянути досвід Завалівського ГЗК при вирішенні цих проблем.

Виклад основного матеріалу. В даний час промисловістю виробляється понад 500-600 найменувань сортів і марок графітової продукції. Графіт у природі є досить 
поширеним мінералом. Завдяки своїй унікальній структурі i властивостям (мастильність, низький ко ефіцієнт температурного розширення, гарні тепло- i електропровідність, податливість і в'язкість в широких температурних межах, хімічна інертність і нетоксичність та ін.) при родний графіт має широке застосування в різних галузях: металургії, електротехнічній та хімічній промисловостях, машинобудуванні, зокрема для виробництва ливарних форм, тиглів, реторт, вогнетривів, акумуляторів, електродів, метало-графітових виробів, колоїдно-графітових препаратів тощо. Окрім того, як алотропна модифікація вуглецю, графіт має надзвичайно важливе наукове значення, зокрема для аналізу походження та еволюції органічного світу, вуглеводнів та ін. На даний час, завдяки новітнім досягненням світової науки, галузі використання вуглецю постійно розширюються. Достатньо згадати такі природні та синтезовані різновиди як алмаз, лонсдейліт, карбін, фулерени та ін. Фулере́ни або бакіболи - одна 3 кількох алотропних модифікацій Карбону. Найвідоміший фулерен - молекула $\mathrm{C}_{60}$, яка має ідеальну форму футбольного м'яча. Відкриті в 1985 Робертом Керлом, Гарольдом Крото й Річардом Смолі, ці молекули, що складаються тільки 3 атомів Карбону, отримали свою назву на честь Річарда Бакмінстера Фулера - архітектора, що прославився побудовою ажурних куполів. Першовідкривачі отримали Нобелівську премію з хімії в 1996 році. Останніми роками на основі графіту було отримано новий перспективний матеріал - графен [6,7].

Цей вид сировини належить до категорії В. Родовища кристалічного графіту виявлені в межах Українського кристалічного щита. Державним балансом запасів корисних копалин враховано шість родовищ кристалічного графіту із загальними запасами 17,4 млн тонн графіту (рис.1).

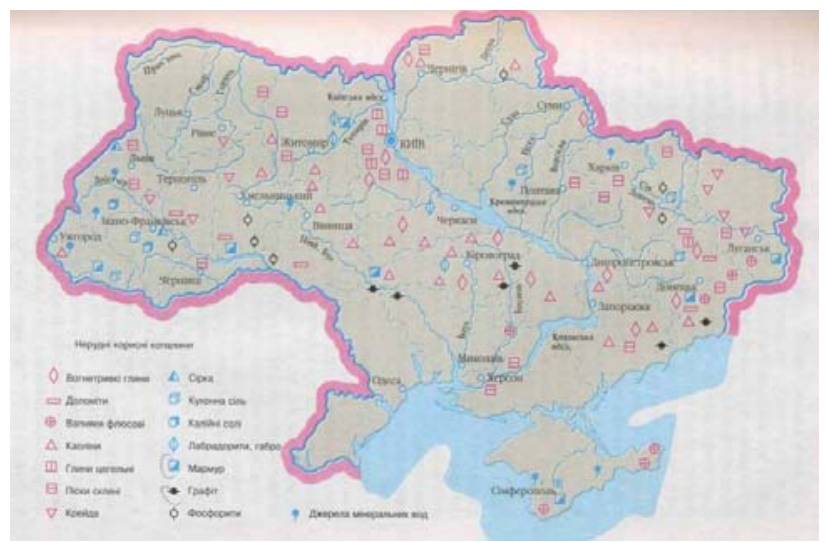

Джерело:[1]

Рисунок 1 - Нерудні корисні копалини

Розробляється Завальївське родовище із загальними запасами 6,8 млн тонн графіту а також Балахівське родовище, загальні запаси якого становлять 2,1 млн тонн графіту.У цьому напрямі передбачається пошукова оцінка запасів та ресурсів графіту на перспективних ділянках та на флангах відомих родовищ [1].

Категорія В - види мінеральної сировини, родовища яких в Україні наявні, запаси їх (у тому числі значні) розвідані, але сировина видобувається в обмежених обсягах або не видобувається взагалі. Згідно з техніко-економічними розрахунками така мінеральна сировина при сучасному становищі економіки країни не $\epsilon$ конкурентоспроможною порівняно з імпортною сировиною і не може бути рентабельно перероблена на вітчизняних підприємствах відповідно до діючих технологій. Водночас 
потреба в такій сировині може відновитися як результат освоєння новітніх технологій збагачення або попередньої переробки відповідних руд [1].

Графітові руди за структурно-текстурними ознаками поділяються на явно та приховано кристалічні. Перший тип поділяється на щільнокристалічний та лускатий різновиди, що мають найбільшу промислову цінність. Лускаті руди з вмістом графіту понад 3\% є промисловими внаслідок спрощеної технології збагачення, що полягає в розмелюванні і селективній флотації графіту 3 одержанням концентратів високої чистоти. Щільнокристалічний різновид утворює масивні чи вкраплені руди з вмістом 15-90\% графіту. Багаті руди піддають ручній рудорозборці, бідні збагачують. Серед прихованокристалічного графіту виділяють щільну та тонкодисперсну відміни, він набуває промислового значення при вмісті його в рудах 80-90\%, оскільки не збагачується флотаційним методом, а піддається тільки розмелюванню. Руди графіту контрастні в геоелектричних полях і добре фіксуються методами електророзвідки завдяки дуже низькому опору.

Основні галузі застосування природного графіту: - металургія (виробництво тиглів, ливарних форм, вогнетривів, протипригарних фарб); - нафтогазова галузь; електрохімія; -машинобудування, авіаційна та космічна техніка(гальмівні колодки і накладки, самозмащувальні механічні частини - підшипники і вкладки). У зв'язку з заміною азбесту у виробництві гальмівних накладок різко зросла доля графітного компоненту з 1-2 до 15\%; - атомна промисловість використовує виготовлені з графіту блоки та деталі реакторів. Традиційною галуззю застосування графіту залишається виробництво олівців. На сучасному етапі світові запаси графіту є значними, ними володіють більшість країн світу. Проте, розподіл цих запасів територіально нерівномірний, тому лише деяких держав видобуток даної сировини є рентабельним. Основні поклади графітових руд (86 \%) зосереджені в Китаї. Значними запасами, особливо з огляду на порівняно невелику територію, володіють Мексика, Чехія та Мадагаскар. Темпи видобутку графіту в кожній 3 цих країн різні. Так, наприклад, країна, що володіє меншими запасами (Бразилія), видобуває більше сировини, ніж країна 3 більшими запасами (Мексика). Тобто для економіки кожної держави графітовидобувна галузь має різну значимість. Вартість природного графіту та диференціація цін визначається за його сортами - найбільша ціна визначена для типу графіту з максимальним вмістом вуглецю в даному сорті. У 2006 р., коли постачання природного графіту були широко доступні, головним чином - 3 Китаю, ціни на сировину були низькі. До 2008-2009 рр. ціни досягають максимуму внаслідок браку постачань (рис. 3). Причиною стало зниження обсягів експорту китайського графіту в 2008 р. Ціновий максимум на природний графіт відзначений у серпні-вересні 2008 р., на початку 2009 р., після незначного спаду, ціни знову починають рости. Середня ціна за тонну кристалічного графіту з вмістом вуглецю 94-97 \% за період часу 2004- 2009 рр. збільшилася в середньому на 44-50 \% [3].

За запасами, видобутком руди та виробництвом кристалічного графіту Україна $є$ однією з перших серед країн СНД. На території України родовища і прояви графіту приурочені до порід архею та нижнього протерозою. Графітоносна провінція Українського щита включає в себе чотири графітоносні райони - Волинський (Буртинське), Побузький (Завалівське), Криворізький (Балахівське, Петрівське родовища) та Приазовський (Троїцьке, Маріупольське) [2]. Адміністративно родовища приурочені до Запорізької, Кіровоградської, Донецької та Хмельницької областей. Найбільша кількість запасів графіту припадає на Кіровоградську область за рахунок розміщення на іiі території запасів Завалівського та Балахівського родовищ (рис. 2, 
табл.2). Значні запаси Хмельницької області обумовлені розміщенням на іiі території Буртинського графітового родовища (табл. 2).
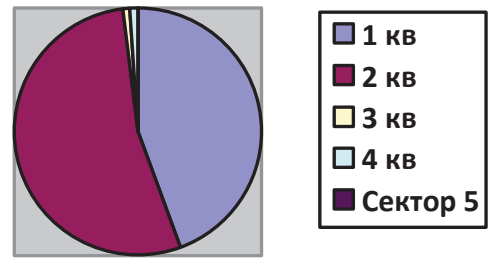

Рисунок 2 - Розподіл запасів графіту по областях: 1- Хмельницька (44,58\%); 2 - Кіровоградська $(53,41) ; 3$ - Запоріжська $(1,1 \%) ; 4$ - Донецька $(0,9 \%)$

Джерело: [6]

Балахівське родовище графіту розташоване в Петрівському районі Кіровоградської області, за1,0 км на північний схід від с.Балахівка.

Згідно 3 державним балансом запасів корисних копалин України «Графіт» станом на 01.01.2018 р. запаси Південної ділянки Балахівського родовища становлять (табл.1).

Таблиця 1 - Запаси корисних копалин Балахівського родовища

\begin{tabular}{|l|c|c|c|c|}
\hline & $\mathrm{B}$ & $\mathrm{C}_{1}$ & $\mathrm{~B}_{1} \mathrm{C}_{1}$ & $\mathrm{C}_{2}$ \\
\hline Руда, тис.т. & 4326 & 19610 & 23936 & 18469 \\
\hline Графіт, тис. & 289 & 1013 & 1302 & 820 \\
\hline
\end{tabular}

Джерело: [1]

Таблиця 2 - Ступінь геологічної вивченості та величина запасів

\begin{tabular}{|l|l|l|l|l|l|l|l|l|l|l|}
\hline \multirow{3}{*}{ Родовище } & \multicolumn{3}{|c|}{ Запаси графіту на основних графітових родовищах України, тис. т } \\
\cline { 2 - 12 } & \multicolumn{2}{|c|}{ А } & \multicolumn{2}{|c|}{ В } & \multicolumn{2}{c|}{ C1 } & \multicolumn{2}{c|}{ A+B+C1 } & \multicolumn{2}{c|}{ C2 } \\
\cline { 2 - 11 } & руда & графіт & Руда & графіт & руда & графіт & руда & графіт & руда & графіт \\
\hline Троїцьке & & & & & & & 20,27 & 163 & 252 & 14 \\
\hline Петрівське & 2002 & 125 & 650 & 42 & 4871 & 373 & 7523 & 540 & 1696 & 115 \\
\hline Маріупольське & 149 & 7 & 248 & 10 & 3043 & 118 & 3440 & 135 & 1347 & 41 \\
\hline Завалівське & & & 17489,1 & 1210,4 & 77701 & 4836,8 & 62526 & 263 & 14613 & 744,2 \\
\hline Балахівське & & & 4326 & 289 & 19610 & 1013 & 23,936 & 1,302 & 18469 & 820 \\
\hline Буртинське & & & 28165,3 & 1736 & 85225,6 & 4848,7 & $113390,6584,7$ & 16586,7 & 898,9 \\
\hline
\end{tabular}

Джерело: [1]

Видобуток графіту в Україні, з огляду на різні, переважно економічні причини, має досить непостійний характер (рис. 1). На сучасному етапі промисловому освоєнню піддаються руди Завалівського родовища (Кіровоградська обл.), розвідані запаси яких за категоріями $\mathrm{A}+\mathrm{B}+\mathrm{C}_{1}$ та $\mathrm{C}_{2}$ становлять відповідно 62526 тис. i 14613 тис. тонн. Родовище розташоване біля р. Південний Буг на території Гайворонського району Кіровоградської області i, частково, Савранського району Одеської області. В районі Завалівського родовища (до 30 км від комбінату) виявлено низку перспективних рудопроявів графіту. Вони сконцентровані переважно на родючих орних землях i характеризуються значною потужністю розкривних порід.

У наведених нижче таблицях дано основну характеристику графітових родовищ України, що враховані державним балансом: середній вміст графіту, група складності родовища, потужності рудних тіл та порід перекриття, ступінь геологічної вивченості, 
величина запасів тощо. Дані показники в багатьох випадках визначають перспективність родовища для промислової розробки. Важливою умовою при освоєнні родовища $\epsilon$ характер порід перекриття, адже більш економічно привабливим $\epsilon$ родовище, де породи перекриття також викликають промисловий інтерес і можуть розроблятися супутньо (Завалівське, Балахівське, Буртинське) (табл. 3).

На даний час експлуатується Завалівське родовище (ВАТ "Заваллівський графітовий комбінат" державного концерну "Укрцемент" розробляє Південно-Східну ділянку, проектна потужність - 35 тис. т. графітового концентрату), Балахівське та Буртинське готуються до використання і перебувають на державному балансі України.

Таблиця 3 - Основні геологічні параметри графітових родовищ України

\begin{tabular}{|c|c|c|c|c|c|c|}
\hline \multirow[t]{2}{*}{$\begin{array}{l}\text { Потужність } \\
\text { порід }\end{array}$} & \multirow{2}{*}{\begin{tabular}{|c|} 
Родовище \\
пере- \\
криття \\
\end{tabular}} & \multirow{2}{*}{$\begin{array}{c}\text { Група } \\
\text { складності } \\
\text { геологічної } \\
\text { будови }\end{array}$} & \multirow{2}{*}{$\begin{array}{c}\text { Потужність } \\
\text { рудного } \\
\text { тіла, м } \\
\text { (макс.) }\end{array}$} & \multicolumn{2}{|c|}{$\begin{array}{c}\text { Вміст } \\
\text { графіту } \\
\text { (середній) }\end{array}$} & \multirow{2}{*}{$\begin{array}{c}\text { Промислове значення та } \\
\text { характер порід } \\
\text { перекриття }\end{array}$} \\
\hline & & & & від & до & \\
\hline Троїцьке & 3 & 300 & 8,04 & 0,2 & 8 & $\begin{array}{l}\text { розміщено в санітарно- } \\
\text { охоронній зоні Бердян- } \\
\text { ського водосховища }\end{array}$ \\
\hline Петрівське & 3 & 50 & 7,18 & 3,5 & 20 & малопродуктивні землі \\
\hline Маріупольське & 2 & 250 & 3,92 & 0,7 & 35 & $\begin{array}{l}\text { орні та малопродуктивні } \\
\text { землі }\end{array}$ \\
\hline Завалівське & 2 & 80 & 6,2 & 8 & 45 & $\begin{array}{l}\text { будівельний камінь, } \\
\text { піски, глини (пром.знач) }\end{array}$ \\
\hline Балахівське & 2 & 300 & 4,94 & 2 & 10,3 & піски та глини (пром.зн) \\
\hline Буртинське & 2 & 49 & 5,85 & 20 & 36 & глини (пром.зн.) \\
\hline
\end{tabular}

Хоча Маріупольське родовище не розробляється, Маріупольський графітовий комбінат, який був повністю зруйнований та відновлений на новому місці східної частини міста, активно експлуатується ВАТ "Маркограф" i випускає графітову продукцію. Сировиною для комбінату слугують відходи металургійних комбінатів, підприємств електротехнічної промисловості та ін. Частково ввозиться концентрат із Завалівського комбінату. Маріупольський комбінат випускає 3 види графіту: акумуляторний, мастильний i графіт для спецсталі.Система управління якістю виробництва продукції сертифікована згідно з міжнароднис стандартом ISO 9001.

Гнучкість виробництва, наявність достатніх технологічних ресурсів дозволяють виготовляти як традиційні види продукції, так і нові марки графітів і змазок за індивідуальними заказами споживачів в відповідних об'ємах та строках.У найбільшому та освоєному Побузькому районі на базі Завалівського родовища діє однойменний графітовий комбінат, що на 70-80 \% забезпечував усі потреби колишнього СРСР, а Україна була практично монополістом із виробництва графітової продукції. 3 глибиною мінеральний склад та фізичні властивості руд, від яких залежить послідовність флотаційного процесу, змінюються. У зв'язку з цим виділено три основних промислових типи руд: пухкі, напівпухкі та щільні. Найбільшої зміни мінерального складу зазнають пухкі руди, які в залежності від набору гіпергенних мінералів та їх кількості поділяються на окремі підтипи, що передбачають використання їх в процесі усереднення та збагачення. Характеристика типів руд та їх збагачуваності подана нижче. 
Руди Буртинського графітового родовища близькі за хімічним складом до руд Завалля (табл. 4). В рудах спостерігається порівняно підвищений вміст сірки сульфідної, окисного і закисного заліза, що пов'язано з наявністю більшої кількості сульфідних мінералів. Породоутворюючі мінерали руд на обох родовищах досить близькі. У той же час на Завалівському родовищі в значній кількості присутній гранат (20\%), а також помітно вищий вміст сульфідів (2-7\%) порівняно з Буртинським.

За фізично-механічними властивостями на Городнявській ділянці виділяються три основні типи руд: (каолін-жорств'яниста кора вивітрювання), напівпухкі (зона дезінтеграції з частковою каолінізацією) і щільні руди (скельні породи).

До щільного різновиду руд віднесені графітові руди, пов'язані із свіжими не порушеними процесами вивітрювання графітовмісними породами. Найбільш характерною особливістю цих руд $\epsilon$ їх висока (в порівнянні 3 рудами 3 кори вивітрювання) міцність, а також те, що луски графіту знаходяться в щільному зростанні 3 іншими мінералами материнської породи. Це негативно впливатиме на показники збагачуваності руд. Попередньо до промислового типу А. Д. Додатком та М. М. Янгічером [9] було запропоновано відносити лише пухкі руди, що пояснювалось відпрацьованою, перевіреною та економічно обгрунтованою технологією їх збагачення. Однак вивчення технологічних проб різних типів руд Завалівського родовища показало, що отриманий графіт щільних руд повністю відповідає вимогам промисловості.

Таблиця 4 - Порівняльна таблиця хімічного складу графітових руд Завалівського родовища і Городнявської ділянки Буртинського родовища

\begin{tabular}{|l|l|l|l|l|l|l|}
\hline \multirow{2}{*}{ Компоненти } & \multicolumn{5}{|c|}{ В м і с т к о м п е н т і в, \%\% } \\
\cline { 2 - 7 } & $\begin{array}{l}\text { Завалівське родовище } \\
\text { руда }\end{array}$ & $\begin{array}{l}\text { напівпухка } \\
\text { руда }\end{array}$ & $\begin{array}{l}\text { щільна } \\
\text { руда }\end{array}$ & $\begin{array}{l}\text { пухка } \\
\text { руда }\end{array}$ & $\begin{array}{l}\text { напівпухка } \\
\text { руда }\end{array}$ & $\begin{array}{l}\text { щільна } \\
\text { руда }\end{array}$ \\
\hline $\mathrm{SiO}_{2}$ & 63,81 & 56,55 & 59,24 & 62,47 & 64,12 & 63,43 \\
\hline $\mathrm{Al}_{2} \mathrm{O}_{3}$ & 12,44 & 14,58 & 11,03 & 14,10 & 13,83 & 13,51 \\
\hline $\mathrm{Fe}_{2} \mathrm{O}_{3}$ & 6,98 & 0,91 & 6,53 & 2,72 & 1,79 & 2,16 \\
\hline $\mathrm{FeO}$ & - & 11,20 & - & 1,23 & 1,57 & 1,45 \\
\hline $\mathrm{TiO}$ & 20,60 & 0,97 & 0,37 & 0,54 & 0,52 & 0,46 \\
\hline $\mathrm{MnO}$ & 0,10 & 0,35 & 0,14 & 0,05 & 0,05 & 0,05 \\
\hline $\mathrm{CaO}$ & 0,39 & 1,56 & 3,30 & 1,09 & 1,31 & 0,96 \\
\hline $\mathrm{MgO}$ & 2,09 & 5,20 & 4,21 & 1,06 & 1,28 & 1,26 \\
\hline $\mathrm{K}_{2} \mathrm{O}$ & 2,83 & 2,07 & 2,18 & 2,51 & 2,94 & 3,06 \\
\hline $\mathrm{Na}_{2} \mathrm{O}$ & 0,07 & 0,37 & 1,08 & 1,76 & 2,33 & 2,59 \\
\hline $\mathrm{P}_{2} \mathrm{O}_{5}$ & 0,09 & 0,23 & 0,13 & 0,32 & 0,11 & 0,13 \\
\hline $\mathrm{Scyльф}$ & 2,81 & 2,60 & 3,92 & 0,65 & 1,34 & 1,48 \\
\hline $\mathrm{SO}_{3}$ & - & - & - & 0,23 & 0,32 & 0,24 \\
\hline п.П.П. & 8,46 & 5,81 & 7,98 & 11,07 & 8,56 & 9,04 \\
\hline$\Sigma$ & 100,30 & 100,09 & 100,11 & 99,80 & 100,07 & 99,82 \\
\hline $\mathrm{H}_{2} \mathrm{O}$ & 0,62 & 0,54 & 0,67 & 0,68 & 0,57 & 0,25 \\
\hline
\end{tabular}

Джерело: [6]

На сьогоднішній день в експлуатації перебуває Завалівське родовище, на базі якого діє однойменний збагачувальний комбінат.Руди Завалля збагачуються способом флотації. Така ж схема збагачення, згідно 3 технологічними випробуваннями, передбачена для руд Балахівського та Буртинського родовищ. Проте, в залежності від 
мінерального складу та фізичного стану руд схема флотаційного процесу кожного 3 типів руд відмінна.

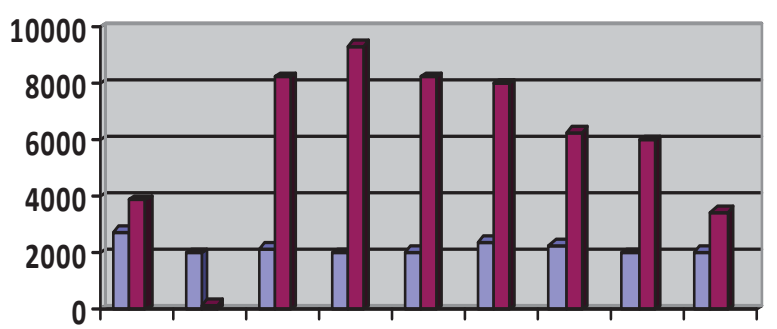

20012003200520072009201120132015

Рисунок 3 - Споживачі та об'єми споживання українського графіту: перша колонка - кількість графіту, що надійшла підприємствам України, т.; друга колонка - кількість графіту, що надійшла на підприємства Близького та далекого зарубіжжя,т.

Джерело: [6]

Основною задачею збагачення $є$ отримання концентрату графітового вуглецю 3 мінімально можливим вмістом мінеральних домішок. Попередньо для визначення доцільності збагачення графіту на стадіях попередньої розвідки проводиться термічна обробка проб графіту в різних температурних інтервалах, у відповідності з якими, та кількістю вуглецю, що згорає, графітвмістна порода характеризується таким чином. Всі породи, в яких графіт вигорає до температури $510^{\circ} \mathrm{C}$, містять графіт непромислової якості; якщо вуглець вигорає більше ніж на $60 \%$ в температурному інтервалі $510-695^{\circ} \mathrm{C}$ - породи становлять промисловий інтерес, в разі, якщо в інтервалі $695-800^{\circ} \mathrm{C}$ вигорає 1-2\% вуглецю - породи мають промислову цінність і повинні піддаватись технологічним дослідженням для розробки методів і режимів збагачення.

Метод збагачення залежить від шкідливих домішок, характеру вміщуючих порід, структури графіту та призначення продукту. На сьогодні в залежності від характеристики руд використовують такі методи, як ручне сортування, вибіркове подрібнення, хімічне, магнітне, термічне збагачення, флотацію. Для збагачення графітових руд УЩ найбільш ефективним $є$ флотаційний метод, як додаткові використовують також магнітну та повітряну сепарацію, хімічне дозбагачення. Флотація дає можливість збагачувати руди 3 вмістом графіту 3-5\%. При цьому флотаційні властивості графіту залежать від структури: кристалічні та лускаті графіти флотуються легко, тоді як прихованокристалічні (аморфні) - погано. Режим флотаційного процесу залежить від мінерального складу (наявність гіпергенних мінералів, наприклад, наявність окислів в рудах знижує гідрофобні властивості графіту в процесі флотації, ускладнюючи збагачення), структурних особливостей (графіт перебуває в зростках з іншими мінералами або вивільнений в результаті їх руйнування) та фізико-механічного стану руд (щільність, тріщинуватість) і визначається після лабораторно-технічних та напівпромислових випробувань руд. Кінцевим етапом флотаційного процесу є марочна класифікація концентрату згідно ДСТУ. Насамперед оцінюється вихід крупнолускатого (тигельного) графіту. За ДСТУ 1702281, вміст класу $+0,2$ мм в тигельному графіті повинен бути не менше 75\%. Решта концентрату розподіляється за зольністю, фізико-хімічними показниками та класом крупності.

Вихід товарних марок Завалівського родовища за даними технологічних випробувань наведено в табл. 5 . 
Таблиця 5 - Товарні марки графіту

\begin{tabular}{|l|l|}
\hline \multicolumn{1}{|c|}{ Марка графіту } & \multicolumn{1}{|c|}{ Тип } \\
\hline Ливарний & ГЛ 1,2,3- до 45,2\% \\
\hline Тигельний & ГТ-1, ГТ-2, ГТ-3 ГОСТ 457675 - до 15,5\% \\
\hline Елементний & $\begin{array}{l}\text { ГЕ-1,ГЕ-2 (крупний) - до 10\%; ГЕ-3, ГЕ-4 (дрібний), ГОСТ } \\
747875-\text { до 12,7\% }\end{array}$ \\
\hline $\begin{array}{l}\text { Олівцевий } \\
\text { спеціальний }\end{array}$ & ГП-1,2,3, ГК-3- до 16,6\% \\
\hline
\end{tabular}

Джерело: [9]

На даний час в Україні існують перспективи розширення сировинної бази графіту. Руди 3 високим вмістом графіту виявлені на Млинківській площі в Кіровоградській області; на Середньому Побужжі виявлено 7 перспективних ділянок (Дубінівська, Демов'ярська, Собатинівська, Східно-Савранська, Котовська, ПівденноХащуватська, Шамраївська). Напрямки розвитку графітовидобувної галузі України прописані у "Загальнодержавній програмі розвитку мінерально-сировинної бази України на період до 2030 року" [1, с. 241], де першочерговими завдяннями $є$ виявлення активних запасів графіту на території Української графітоносної провінції, проведення оціночних робіт по вже виявлених ділянках та модернізація виробництва на Завалівському графітовому комбінаті за рахунок випуску принципово нових дефіцитних виробів із терморозширеного та силіцируваного графіту для різних галузей промисловості, ракетно-космічної техніки тощо

Висновки. 1. Промислові типи руд найбільших за запасами родовищ УЩ визначаються за рядом ознак: фізичний стан порід, мінералогічний склад, спосіб збагачення. Останній визначає необхідність виділення та врахування при усередненні підтипів пухких руд, що включають монтморилоніт-гідрослюдисту та каолінову відміни на Завалівському родовищі, каолініт-хлорит-гідрослюдисту та каолінову на Балахівському та каолінову на Буртинському родовищах.

2. Промислове значення руд Завалівського родовища $є$ вищим, ніж решти об'єктів, оскільки їх збагачення дозволяє отримати майже всі товарні марки графіту. Якщо враховувати, що найбільш цінним є графіт тигельний (ГТ), то за цим показником Завалівське родовище помітно перевищує Буртинське майже в чотири рази.

3. Технології збагачення руди, що використовуються Завалівським ГЗК, передбачають застосування найбільш економічно вигідних складових флотації та забезпечують ефективне використання руд.

\section{Список літератури}

1. Державний баланс запасів України. Київ. 2018.

2. Закон України «Про затвердження Загальнодержавної програми розвитку мінерально-сировинної бази України на період до 2030 року», від 10.06.2012 p.

3. Загнітко В., Лижеченко Н. Динаміка видобування та реалізація графіту в Україні та світі. Вісник КНУ ім. Тараса Шевченка. Геологія. 2012. Вип.58. С. 32-35.

4. Металічні і неметалічні корисні копалини України : монографія. Т. 1. Металічні корисні копалини / Д. С. Гурський та ін.; Держ. геол. служба України НАН України. К. : Центр Європи. 2006. 739 c.

5. Каталог базових цін на матеріальні ресурси, що використовуються при геолого-розвідувальних роботах // Міністерство охорони навколишнього природного середовища. УкрДГРІ.

6. Мінеральні ресурси України. Державне науково-виробниче підприємство “Геоінформ України”. Київ 2009. 602 с.

7. Geim, A.K. Graphene: status and prospects. Manchester Centre for Mesoscience and Nanotechnology, University of Manchester, Oxford Road, Manchester. DOI: 10.1126/science.1158877 
8. Брагина В. И., Брагин В. И. Флотационные методы обогащения: учебное пособие. Красноярск, 2010. 277 c.

9. Додатко А. Д., Янгичер Н. Н., Карпенко Н. Н. К вопросу о промышленных типах руд графитовых месторождений Украинского щита. Геологический журнал. 1981. Т. 41, № 2. С.143-147

10. Заяц Н. Н. Производство и применение чешуйчатого графита Завальевского месторождения: монография (рукопись). Завалье. 2004. 24 с.

11. Смирнов В. О., Білецький В. С. Флотаційні методи збагачення корисних копалин. Донецьк: Схід. видавн. дім. 2010. 492 с.

\section{Referencis}

1. $\quad$ State balance of stocks of Ukraine. (2018). Kyiv [in Ukrainian].

2. The Law of Ukraine "On Approval of the National Program for the Development of the Mineral Resources of Ukraine until 2030". (n.d.). (dated 10.06.2012) [in Ukrainian].

3. Zahnitko, V. \& Lyzhechenko, N. (2012). Dynamika vydobuvannia ta realizatsiia hrafitu v Ukraini ta sviti [[Dynamics of extraction and sale of graphite in Ukraine]. Visnyk KNU im. Tarasa Shevchenka. Heolohiia Visnyk - Visnyk Taras Shevchenko National University of Kyiv. GEOLOGY, Vol.58, $32-35$ [in Ukrainian].

4. Hurs'kyj, D.S. et al. (2006). Metalichni i nemetalichni korysni kopalyny Ukrainy [Metallic and nonmetallic minerals of Ukraine], Vol. 1. Metalichni korysni kopalyny; Derzh. heol. sluzhba Ukrainy NAN Ukrainy. Kyiv: Tsentr Yevropy [in Ukrainian].

5. Catalog of basic prices for material resources used in geological exploration works. Ministerstvo okhorony navkolyshn'oho pryrodnoho seredovyscha. UkrDHRI [in Ukrainian].

6. Mineral'ni resursy Ukrainy [Mineral resources of Ukraine]. (2009). Derzhavne naukovo-vyrobnyche pidpryiemstvo "Heoinform Ukrainy". Kyiv [in Ukrainian].

7. Geim, A.K. (2009). Graphene: status and prospects. Manchester Centre for Mesoscience and Nanotechnology, University of Manchester, Oxford Road, Manchester. DOI: 10.1126/science.1158877

8. Bragina, V.I. \& Bragin, V.I. (2010). Flotacionnye metody obogashhenija [Flotation methods of enrichment]. Krasnojarsk [in Russian].

9. Dodatko, A.D., Jangicher, N.N. \& Karpenko, N. N. (1981). K voprosu o promyshlennyh tipah rud grafitovyh mestorozhdenij Ukrainskogo shhita. [On the issue of industrial types of ore from graphite deposits of the Ukrainian shield]. Geologicheskij zhurnal - Geological Journal. Vol. 41, № 2. 143-147 [in Russian].

10. Zajac, N.N. (2004). Proizvodstvo i primenenie cheshujchatogo grafita Zaval'evskogo mestorozhdenija [Production and application of flake graphite Zavalievskogo field]. Zaval'e [in Russian].

11. Smyrnov, V.O. \& Bilets'kyj, V.S. (2010). Flotatsijni metody zbahachennia korysnykh kopalyn [Flotation methods of copying kalinis]. Donets'k: Skhid. vydavn. dim [in Ukrainian].

Volodymyr Kropivnyy, Prof., PhD tech. sci., Ludmila Molokost, lecturer, Olexandr Kuzyk, Assoc. Prof., $\mathrm{PhD}$ tech. sci., Alena Kropivnaya, Assoc. Prof., PhD tech. sci.

Central Ukrainian National Technical University, Kropyvnytskyi, Ukraine

\section{Comparative Industrial Assessment of Graphite Deposits and Ores of Ukraine, Characteristics of Ore Concentration}

In the article the basic deposits of graphite in Ukraine, methods of enrichment of graphite ores depending on degree of their physical and chemical changes are considered, the industrial estimation is made, the most perspective objects for development are defined.

On the example of the three largest graphite deposits of the Ukrainian shield, the problem of enrichment of graphite ores, as well as the principles of their separation into industrial types, the characteristic of graphite ores and properties of graphite, the use of graphite in industry are given. The properties of this mineral allow you to use it as and carbon in General, in all sectors of the national economy, science and technology. The main fields of application of natural graphite: - metallurgy (production of crucibles, foundry molds, refractories, antistick paints); - oil and gas industry; -electrochemistry; -engineering, aviation and space technology (brake pads and pads, self-lubricating mechanical parts - bearings and pads).

Peculiarities of graphite market conjuncture are determined that provides analysis of dynamics of extraction, production, consumption of mineral raw materials in Ukraine and in the world.

graphite, graphite deposits, quality, reserves, ore concentration

Одержано (Received) 25.04.2019

Прорецензовано (Reviewed) 30.04.2019

Прийнято до друку (Approved) 04.06.2019 